\title{
AS ORIGENS DA TEORIA DO PODER CONSTITUINTE: O ABADE SIEYÈS E A REVOLUÇÃO FRANCESA
}

\section{THE ORIGINS OF CONSTITUENT POWER THEORY: ABBOT SIEYÈS AND THE FRENCH REVOLUTION}

\author{
Marcos Leite Garcia ${ }^{1}$
}

\section{RESUMO}

O presente trabalho tem como objetivo discutir as origens do Poder Constituinte na Revolução Francesa a partir da obra do abade Emmanuel-Joseph Sieyès. O momento histórico do início da Revolução será fundamental para o entendimento da construção teórica do poder constituinte. A deflagração do movimento revolucionário a partir da transformação da Assembléia dos Estados Gerais em Assembléia Nacional Constituinte é o essencial fundamento para a titularidade legítima do exercício do Poder Constituinte até os dias de hoje.

Palavras-chave: Poder Constituinte; Estados Gerais; Assembléia Nacional; Revolução Francesa; Terceiro estado.

\begin{abstract}
The present work aims at discussing the origins of the Constituent Power in the French Revolution from the work of Emmanuel-Joseph Sieyès. The historical moment of the beginning of the Revolution will be crucial for the understanding of the theoretical construction of the constituent power. The outbreak of the revolutionary movement from the transformation of the General Assembly into the National Constituent Assembly is the essential foundation for the legitimate ownership of the exercise of the Constituent Power to this day.
\end{abstract}

Keywords: Constituent Power; General States; National Assembly; French Revolution; Third State.

\footnotetext{
${ }^{1}$ Doutor em Direito. Professor do Programa de Pós-Graduação Stricto Sensu em Ciência Jurídica da Universidade do Vale do Itajaí-SC. Também professor do Programa de Pós-Graduação em Direito da Universidade de Passo Fundo Rio Grande do Sul (Brasil) E-mail: mleitegarcia@terra.com.br
} 


\section{INTRODUÇÃO}

O padre católico Emmanuel-Joseph Sieyès (1748-1836), até 1788, era então um simples e desconhecido vigário da paróquia de Chartres, situada na periferia de Paris. Seus biógrafos dizem que não tinha muita vocação para o sacerdócio e sim para a política (MADELIN, 2004, p. 305). No final de 1788 escreve um Ensaio sobre os privilégios e nos inícios de 1789 seu famoso panfleto, livro de menos de 100 páginas, que tem como título a pergunta: O que é o Terceiro Estado? Também na mesma época será eleito deputado pelo Terceiro Estado pelos parisienses, e a partir de sua famosa obra e atuação como parlamentar desempenhará um papel decisivo em junho de 1789, na transformação dos Estados Gerais em Assembléia Nacional e na resistência ao Rei Luís XVI e a instituição do Estado absolutista. A atual doutrina do Direito Constitucional enfatiza que é do vigário de Chartres o pai da teoria do Poder Constituinte, que até hoje preside os processos de constitucionalizações democráticas, expresso na sua obra Qu'est-ce que le tiers état? ou como na tradução em português: A Constituinte Burguesa: o que é o Terceiro Estado? Não cabe dúvida que o chamado Abade Sieyès será uma peça fundamental na construção do constitucionalismo moderno ${ }^{2}$. Conceitua o movimento conhecido como constitucionalismo o italiano Maurizio Fioravanti (2014, p. 9) com as seguintes palavras: "El constitucionalismo es, desde sus orígenes, una corriente de pensamiento encaminada a la consecución de finalidades políticas concretas consistente, fundamentalmente, en la limitación de los poderes públicos y en la consolidación de esferas de autonomía garantizadas mediante normas".

Podemos afirmar que a construção teórica do Poder Constituinte nasce na Revolução Francesa a partir da obra do abade Emmanuel-Joseph Sieyès. Pelo menos esse é um senso comum arraigado e consagrado pela doutrina constitucional de nossa era. Ainda que o precedente da Convenção da Filadélfia de 1787, e as anteriores constituições da Confederação Americana como

\footnotetext{
${ }^{2}$ Interessante a inclusão de Maurizio Fioravanti (2001, p. 111-112) do Abade no panorama do constitucionalismo moderno: "(...) Emmanuel-Joseph Sieyès, ciertamente el más lúcido de los intérpretes de la revolución, en su célebre ensayo sobre el Tercer Estado(...), saca de la nueva y potente imagen del poder constituyente consecuencias bastantes distintas a las de los revolucionarios americanos. (...). [Cuando] (...) pone de relieve el aspecto de los límites a los poderes constituidos que se contiene en la constitución instaurada por el mismo poder constituyente. Pero no se queda ahí. Al menos con igual fuerza sostiene que la constitución que limita los poderes constituidos no puede de ninguna manera limitar al poder constituyente: la nación, que es para Sieyès el sujeto soberano, 'no debe encerrarse en las trabas de una forma positiva', y 'no debe ni puede someterse a formas constitucionales'. Se trata de páginas bastante claras, en las que aparece con fuerza la cuestión de la soberanía y la necesidad de encender el motor de la revolución, y de dejar que él guíe la revolución a su resultado. La constitución deberá disciplinar los poderes que la misma revolución instituye, pero nunca podrá pretender apagar ese motor".
} 
a da Virgínia nos deixam em dúvida quanto ao citado consenso ${ }^{3}$. Porém reconhecer as origens intelectuais que permeiam os valores de nosso atual Direito Constitucional faz-se necessário e urgente em nossa sociedade atual. Uma vez que nas últimas décadas temos assistido a proliferação de um sem fim de teorias que negam os valores constitucionais mais fundamentais, como o exercício do Poder Constituinte somente em ocasiões especialíssimas. Ademais de que no último ano (2016) nossa Constituição Federal tenha sido pisoteada pelos poderes legislativo e judiciário nos últimos acontecimentos que maculam a nossa pretensa e recente democracia. Interesses dos mais variados, alguns até concebidos em bases pouco sólidas, oportunistas da ignorância endêmica vigente, e fundamentados em preconceitos classistas ou de outras origens. Alguns desses interesses podem causar danos enormes em sociedades periféricas como a nossa, em favor de alguns privilegiados. O exercício do Poder Constituinte, originário ou não, deveria ser um assunto tratado de forma mais séria pela mídia em nosso entorno. É um assunto que deveria ser também discutido fora da academia.

O objetivo do presente trabalho é apresentar, preliminarmente, algumas questões relacionadas com o Poder Constituinte, a obra do abade Emmanuel-Joseph Sieyès e a Revolução Francesa.

É indiscutível a importância do bom entendimento da Teoria do Poder Constituinte no contexto do Direito atual. Uma vez que o exercício do Poder Constituinte é ilimitado, inicial e incondicionado e deve somente ser exercido em momentos políticos muito especiais e não banalizados como pretendem alguns em nosso contexto político-social. Um texto constitucional não prevê o seu próprio fim. As normas constitucionais definidoras de Direitos (direitos fundamentais), consagradas em nosso texto de 1988, são o coração e a cabeça das atuais constituições ocidentais e felizmente em nosso texto constitucional de 1988 - consideradas como o núcleo imodificável (cláusulas pétreas) do mesmo -. Estamos em plena era do constitucionalismo contemporâneo (para alguns pós-positivismo ou neoconstitucionalismo, ou ainda: neopositivismo, constitucionalismo garantista, como preferem outros ou mesmo da Democracia Constitucional, terminologia mais abrangente), e os vetores que regem todo o sistema de normas são valores de direitos fundamentais. Já é hora de colocar os direitos fundamentais e as questões da cidadania em seu devido lugar: como disciplina autônoma nos currículos das universidades brasileiras, não somente nos cursos de Direito, e colocá-los em pauta

\footnotetext{
${ }^{3}$ Sobre o constitucionalismo norte-americano e a importância de seus debates sobre as questões de como deveria ser a futura constituição, entre outros, veja-se as obras de Dippel (2007), Fioravanti (2001) Ruiz Miguel (2002) e o clássico Os Federalistas de James Madison, Alexandre Hamilton e John Jay (1993).
} 
em diversos debates - principalmente naqueles dirigidos a um maior número de cidadãos possível.

\section{A ASSEMBLÉIA DOS ESTADOS GERAIS}

A revolução francesa é um dos acontecimentos mais importantes da história da humanidade, como sabemos será determinante nas mudanças profundas da sociedade moderna desde a positivação dos direitos fundamentais e será essencial para o constitucionalismo moderno e contemporâneo.

Devido a uma série de fatores econômicos e políticos ${ }^{4}$, o Rei Luis XVI resolve convocar no final de 1788 aos chamados Estados Gerais, a Assembléia Nacional que reuniria as três ordens ou três Estados: o clero, a nobreza e os comuns, conhecidos também estes últimos, de acordo com sua posição hierárquica, como o terceiro Estado. Os Estados Gerais não eram convocados desde $1614^{5}$, e sua convocação levou a que as três ordens organizassem as questões a serem discutidas nos chamados cadernos de queixas (cahiers de doléances) ${ }^{6}$, que condensavam os desejos de reformas que antecedem a Revolução, já que esta era uma época marcada pela tentativa de reorganização e discussão dos problemas da sociedade francesa.

Para os Estados Gerais se organizaram eleições, evidentemente que de maneira diferente que em 1614, chegou-se a um acordo que a terceira ordem teria o dobro de deputados que os

\footnotetext{
${ }^{4}$ Entre esses fatores principalmente uma grave crise econômica marcada pela fome do povo por culpa de uma péssima safra dos anos 1787 e 1788 e da ajuda da França à Revolução de Independência das ex-colônias inglesas que formariam os Estados Unidos da América, e também devido a uma revolta da aristocracia mais tradicional. Sobre essa revolta da aristocracia, veja-se Lefevbre (1989, p. 41-54).

${ }^{5}$ Como muito bem descreve Albert Mathiez com relação ao Terceiro Estado em 1614 “(...) as cidades haviam sido representadas por delegados de suas municipalidades oligárquicas, e as províncias do Estado por deputados eleitos pelos próprios Estados, sem intervenção da população". E concluiu que "adotando essa antiga norma, o terceiro Estado seria representado apenas por uma maioria de incapazes enobrecidos” (MATHIEZ, s.d., p. 44).

${ }^{6}$ Quanto ao estudo desses cadernos de queixas, George Lefebvre é categórico ao dizer que "quando os cadernos de queixas de bailiado das diferentes ordens são comparados entre si, constata-se sua unanimidade contra o poder absoluto: as três ordens querem uma constituição que reserve o voto do imposto e das novas leis a Estados Gerais periódicos, que atribua a administração a Estados provinciais eletivos e que garanta a liberdade individual e de imprensa" (LEFEBVRE, 1989, p. 109). Somente recordar que os Estados Gerais, a Assembléia Nacional, não eram convocados desde 1614, há exatos 175 anos, devido ao extremo absolutismo de reis como Luís XIV e Luís XV, respectivamente bisavô e avô do jovem rei Luis XVI.
} 
nobres e o clero. Seria então o Parlamento de Paris ${ }^{7}$ quem iria determinar as regras. E esse parlamento compostos por magistrados determinou em um acórdão de 25 de setembro de 1788 que o funcionamento dos Estados Gerais é que seria igual aos de antes: "regularmente convocados e compostos da mesma maneira que em 1614". Os intelectuais do Terceiro Estado, a sociedade evidentemente não era mais a mesma de 1614, começaram a denunciar uma serie de coisas, entre elas a "venalidade e o caráter hereditário dos cargos judiciários, os abusos das custas em espécie e a negar à magistratura o direito de censurar as leis ou de modificá-las". Além do que, os patriotas, como eram conhecidos os intelectuais do Terceiro Estado, “(...) declaravam abertamente que, depois da reunião dos Estados Gerais, ninguém obedeceria mais à decisões da justiça, porque a nação poderia fazer-se obedecer, melhor que o rei”. Era esta uma clara alusão e provocação pré-revolucionária. Denunciava-se também a inquisição judiciária como mais temível que a dos bispos. Segundo Mathiez (s.d., p.45) diante de todas essas veementes denuncias o Parlamento de Paris intimidou-se e recuou. No dia 5 de dezembro de 1788, em novo acórdão, anulou o precedente, e aceitou o dobro de representantes do Terceiro Estado. "Capitulação alias inútil e incompleta" nas palavras de Albert Mathiez (s.d., p. 45), pois o acórdão nada dizia sobre a votação per capita e assim continuava-se com a votação por ordem. O Parlamento de Paris antes popular agora era execrado por estar a serviço dos privilegiados. Além do que vale lembrar que tal Parlamento não decidia essa questão, quem decidia era o rei através de seu primeiro ministro, o popular Jacques Necker ${ }^{8}$. O clima tenso fez com que um grupo de nobres, chamados $o s$ notáveis por ser composto por cinco príncipes de sangue, evidentemente pronunciara-se a favor das antigas regras dos Estados Gerais e já prevendo algo declararam em 12 de dezembro ao rei que se ele não procurasse manter de qualquer forma os dispositivos tradicionais, a Revolução seria inevitável. Chamavam a atenção os príncipes que os direitos do trono já estavam sendo discutidos (MATHIEZ, s.d., p. 46). Da mesma forma para ganhar a simpatia do rei, os intelectuais do Terceiro Estado enviavam-lhe declarações de lealdade, e assim os príncipes e toda a nobreza pareciam exagerados em suas previsões. Claro, acima de tudo as duas ordens privilegiadas estavam sendo ameaçadas pelas reivindicações plebéias contra seus privilégios tradicionais, a exclusividade dos cargos públicos, sobretudo os militares e da justiça, e na sua propriedade baseada nos direitos feudais.

\footnotetext{
${ }^{7}$ Segundo Lefevbre ser membro do Parlamento de Paris era um privilegio do que ele chama da nobreza de toga, pois esse parlamentos provinciais eram compostos por magistrados pertencentes à nobreza (LEFEVBRE, 1989, p. 46-47). ${ }^{8}$ Necker, o primeiro ministro do Rei Luis XVI, um dos únicos membros do governo de origem burguesa, por isso popular.
} 
Como acontece desde sempre em todas as revoluções contra situações de exceção, as manifestações arrogantes dos que se achavam melhores que os demais, a defesa de seus privilégios e autoridade baseada na tradição e em uma cultura de religião única em crise marcada pela secularização da sociedade (desde a Reforma Protestante), será determinante ao fortalecimento da causa dos patriotas. Necker, o primeiro ministro, “(...) se sentiu com forças para fazer o rei ágil contra os notáveis e os príncipes". Foi concedido então ao Terceiro Estado um número de deputados igual ao das duas ordens privilegiadas reunidas, exatamente 578 deputados $^{9}$. Tanto Mathiez (s.d, p. 53) como Hampson (1970, p. 69) chamam a atenção para o fato de que também foi então permitido que os sacerdotes do chamado baixo clero participassem diretamente das assembléias eleitorais do clero, medida que teve conseqüências terríveis para o poder da nobreza eclesiástica. Mesmo fazendo essas concessões, as novas regras de nada serviam, pois o rei não ousou tocar na questão mais importante de todas: a da votação per capita, deixando a votação por ordem ou para ser discutida sua forma depois de iniciada a reunião dos três ordens (LEFEBVRE, 1989, 96). Exatamente essa votação por ordem será fundamental para o fracasso da forma tradicional de funcionamento dos Estados Gerais e a pólvora para a explosão da revolta do Terceiro Estado. Não fazia sentido o voto por ordens, pois essa forma era um jogo de cartas marcadas uma vez que as duas primeiras ordens - clero e nobreza - unidas, quando fossem discutir seus privilégios (por exemplo: seus direitos feudais, isenção de impostos, reserva de cargos públicos e patentes militares) com as regras de 1614 o resultado seria sempre um dois a um (2x1) em favor dos privilegiados.

\section{A TEORIA DO PODER CONSTITUINTE A PARTIR DA OBRA DO ABADE EMMANUEL-JOSEPH SIEYÈS}

Durante a campanha eleitoral para as três ordens, surgem muitas obras rápidas, os chamados panfletos e libelos pré-revolucionários, escritas na efervescência das questões que levaram a Revolução. A difusão dos panfletos é muito variável, alguns deles têm um público meramente local ao passo que outros como o famoso Qu'est-ce que le Tiers État (O que é o Terceiro Estado), do abade Emmanuel-Joseph Sieyès, com trinta mil exemplares vendidos em alguns dias em janeiro de 1789, são de esfera nacional (PÉRONNET, 1989 p. 124). A obra do abade Sieyès de forma especial irá marcar o futuro do próprio movimento por discutir as regras

\footnotetext{
${ }^{9}$ Os Estados Gerais de 1789 compunham-se de 1.154 representantes: 291 deles eram deputados do clero, 285 da nobreza e 578 do Terceiro Estado.
} 
de funcionamento da Assembléia dos Estados Gerais então recente convocada pelo Rei Luis XVI, como foi visto, na tentativa de dirimir as reivindicações das ordens ainda estamentais que formavam a sociedade francesa do Antigo Regime.

O abade Emmanuel-Joseph Sieyès, então um simples padre da periferia de Paris, Chartres, em 1789 será eleito deputado pelo Terceiro Estado ${ }^{10}$ pelos parisienses, e como já foi dito a partir de sua famosa obra e atuação como parlamentar desempenhará um papel decisivo na Revolução Francesa desde a inauguração dos Estados Gerais em 5 de maio de 1789 no Palácio de Versalhes. Principalmente em 23 junho de 1789 quando do conhecido Juramento do Jogo da Péla (Serment du jeu de paume), que foi um dos marcos iniciais da revolta do Terceiro Estado, quando estes decidiram permanecer reunidos até dotar a França de uma Constituição escrita nos moldes dos Estados Unidos da América, da monarquia parlamentarista inglesa, e sobretudo a partir das regras teorizadas por Sieyès. Essa foi especificamente a transformação dos Estados Gerais em Assembléia Nacional e a resistência ao Rei absolutista. A atual doutrina do Direito Constitucional enfatiza que é basicamente do vigário de Chartres a organização da teoria do Poder Constituinte, que até hoje preside os processos de constitucionalizações democráticas, expresso na sua obra Qu'est-ce que le tiers état? ou A Constituinte Burguesa em sua versão em português. Curioso notar que devido ao seu caráter comedido o abade Sieyès será o único grande nome da Revolução Francesa que sobreviverá aos piores momentos da mesma, talvez por sua posição política marcadamente de centro (a chamada planície) e por ser bastante calado (MADELIN, 2004, p. 305). Entre outras curiosidades de sua biografia, Sieyès votará a favor da constituição civil do clero, em 1790, e pela morte do Luis XVI no final de 1792; sobreviverá à época do terror e será favorável ao golpe de Estado do dia 9 de Termidor (27 de julho 1794); em 1799 introduzirá Napoleão Bonaparte no poder, e será embaixador do mesmo; cairá em desgraça na época da restauração da Monarquia (chamada de Julho - 1815), sendo exilado em Bruxelas e de volta a Paris em 1830 morrerá na cidade luz aos 88 anos em 1836. Certamente é o único personagem importante da Revolução Francesa a morrer ancião. Perguntado em certa oportunidade como fez para sobreviver a tantas épocas, o abade respondeu ironicamente: "apenas sobrevivi" (MADELIN, 2004, p. 328).

Em sua obra de 1789, o abade Sieyès reafirma a doutrina da soberania da Nação, dizendo que "em toda Nação livre - e toda Nação deve ser livre - só há uma forma de acabar com as

\footnotetext{
${ }^{10}$ Os deputados do Terceiro Estado eram na sua maioria juristas, um vigário do baixo clero era uma exceção. Os sacerdotes do Alto Clero tinham a sua ordem-estamento específico: o chamado primeiro Estado dos Estados Gerais da Monarquia Absoluta da França, o antigo regime.
} 
diferenças que se produzem com respeito à Constituição. Não é aos notáveis que se deve recorrer, é à própria Nação" (SIEYÈS, 2001, p. 113). Foi com essa posição que Sieyès confirma, desde uma posição racional, o princípio da soberania da Nação como instrumento de legitimação para a instituição de um Estado baseado no Direito estipulado em um contrato social que deverá ser o estabelecimento prévio das regras de viver em sociedade que será uma constituição escrita pelos representantes da nação. Esta nova forma de organização político-jurídica da sociedade em transformação, segundo Dallari, ao ser concebida "no sentido de Estado enquadrado num sistema normativo fundamental, é uma criação moderna, tendo surgido paralelamente ao Estado Democrático e, em parte, sob influência dos mesmos princípios" (DALLARI, 2007, p. 168.), através de um Poder político e metajurídico, inato ao novo membro da sociedade: o cidadão. O cidadão substitui ao súdito e os direitos do cidadão devem substituir aos privilégios das ordens superiores declarando-se a igualdade entre todos. Seguindo a linha dos livres pensadores modernos, Sieyès pede também o fim das diferenças entre os seres humanos, nada mais racional, nada mais jusracionalista.

O poder de constituir as regras prévias do viver em sociedade é o primeiro poder constituinte, aquele que é inicial, ilimitado e incondicionado ${ }^{11}$, chamado pela doutrina atual de poder constituinte originário. Esse se deve a um acontecimento político e social, é dizer, um acontecimento, um fator, metajurídico, isto é fora do jurídico, não previsto pelo sistema jurídico, não previsto pelo Direito posto. Exatamente desse fator metajurídico, acontecimento político não previsto pelo Direito vigente, surgem as constituições escritas da modernidade. A primeira constituição escrita surge de um fator metajurídico - acontecimento histórico e político - que foi a independência dos Estados Unidos da América. As revoluções políticas e sociais também serão históricos fatores metajurídicos que geraram muitas constituições. Infelizmente por ser inicial, ilimitado e incondicionado, o poder constituinte (originário) poderá ser exercido de forma ilegítima, uma vez entendido que legitimamente é exercido pelo povo, por forças estranhas a vontade popular como por exemplo por um ditador, ou uma elite oligárquica, ou um grupo que através da força bruta detenha o poder como os militares na América Latina em sua conturbada história do século XX. Seria o caso de o poder constituinte ser exercido ilegitimamente a partir do fator metajurídico chamado de golpe de estado, que difere da revolução por não ter ampla participação popular e levar ao poder um ditador ou um grupo que instala uma ditadura. Outro fator metajurídico que gera o exercício do poder constituinte (originário), considerado como

\footnotetext{
${ }^{11}$ Como diz a doutrina do Poder Constituinte, o primeiro e inaugural poder constituinte é o originário, aquele que gera uma nova constituição e é inicial, ilimitado e incondicionado. (CRUZ, 2002, p. 66).
} 
legítimo, seria um processo de redemocratização de uma sociedade. Os exemplos de processos de redemocratizações são muitos, e todo todos eles derivaram assembléias constituintes que geraram constituições democráticas, como os exercidos no pós-guerra a partir de 1945, entre outros, França, Alemanha e Itália, e no final de ditaduras como Portugal e Espanha e certamente o exemplo brasileira que gerou a Constituição de $1988^{12}$.

As origens intelectuais das chamadas revoluções liberais burguesas e do processo de positivação dos direitos fundamentais serão os movimentos individualista, racionalista, iluminista, contratualistas dos autores que iram influenciar as transformações da sociedade feudal a sociedade moderna e que levarão às chamadas revoluções liberais (entre outros: Peces-Barba, 1995, p. 115-144 e Fioravanti, 2001, p. 71-164). O abade Sieyès seguirá essas concepções racionalistas, individualistas e um dos seus grandes méritos será fundamentalmente voltar-se de maneira original, naquele momento pré-revolucionário, para a realização de um documento jurídico, no sentido de dar à nação o direito de produzir sua norma jurídica fundamental: uma Constituição que contenha suas regras prévias da organização e limitações do poder do Estado. Dito de outra forma, o grande mérito de Sieyès será traduzir para o momento (pré) revolucionário a discussão da forma de funcionamento ainda medieval e estamental dos Estados Gerais e sua transformação em uma Assembléia de homens livres, formada por representantes da nação, do povo, na qual cada representante tenha direito a um voto; resumidamente é a luta do povo pelo voto per capita.

Acertadamente e seguindo o espírito da igualdade do Direito Natural Racionalista, dos autores contratualistas e iluministas, o abade Sieyès desconsidera a histórica autoridade das ordens superiores baseada na tradição e na superstição. Na tradição dos históricos costumes e

\footnotetext{
12 Destacamos então que os fatores metajurídicos são acontecimentos históricos especialíssimos que estão fora (meta) ou não previstos pelo mundo jurídico e estes podem ser de quatro maneiras: 1. Quando do nascimento de um país (que pode ser pela independência de uma nação, de um povo ou de um país formado por várias nações, ou mesmo por uma fusão, incorporação, ou separação de povos ou partes de um país); 2. Quando ocorre uma Revolução (que pode levar ou não a uma nova etapa democrática do povo em questão, mas inegável é a necessidade de refundação da nação, povo ou país que faz uma revolução); 3. Quando ocorre um Golpe de Estado (são muito os tipos de Golpes de Estado. Desde os mais violentos como os atuais golpes de estado institucionais dos países latino-americanos como ocorreu em Honduras, Paraguai e Brasil em 2016). 4. Desde um processo de redemocratização (um processo lento e gradual de abertura política e de volta a democracia em um país que viveu anos de ditadura, ou quando do fim de uma guerra). Entre essas quatro formas de exercício do Poder Constituinte Originário, os exemplos são muitos. Ainda que as mesmas podem ser mesclados, por exemplo: uma revolução pode levar à independência de uma nação; uma revolução pode levar a um processo de redemocratização de um país; um golpe de Estado, a forma mais perversa, quase sempre leva a uma ditadura, mas pode levar a um processo de redemocratização, entre outros exemplos. Lembrando sempre da longa controvérsia que existe entre Revolução e Golpe de Estado. Nesse último ponto, interessante o que diz o filósofo espanhol Felipe González Vicén (2010) quando teoriza as revoluções e leciona sobre as diferenças entre golpe de Estado, praticado por um indivíduo, ou um grupo de indivíduos -como os militares ou uma elite econômica- e a Revolução que para assim ser classificada deve ter ampla participação popular.
} 
privilegiados feudais e na superstição da Igreja que justifica e fundamentam os privilégios e o poder do monarca, da nobreza e do clero ${ }^{13}$. No seu famoso livro (Qu'est-ce que le tiers état?) não há nenhuma alusão ao desenvolvimento das instituições nem ao papel histórico da nobreza ou da monarquia, muito pelo contrário, esses são chamados de parasitas da nação. A história que recomeça em 1789 é a dos homens livres, a partir das reivindicações das classes não privilegiadas, dos burgueses, ou seja, da nação ${ }^{14}$. Exatamente no inicio de sua obra, Sieyès empenha-se em demonstrar a importância e utilidade da burguesia e a inutilidade da nobreza parasita. Para o abade, o argumento da utilidade é o principal entre todos por ele utilizados para defender sua tese (CRUZ, 2002, p. 66).

O abade demonstra em sua obra a extrema utilidade do Terceiro Estado, afirmando que o mesmo suportava todos os trabalhos particulares - desde a atividade econômica, desde a exercida na indústria, no comércio, na agricultura, nas profissões científicas e liberais e até nos serviços domésticos -; e ainda exercia a quase totalidade das funções públicas, excluídos apenas aquelas que eram injustamente reservadas aos privilegiados, ou seja, os lugares lucrativos e honoríficos, correspondentes a cerca de um vigésimo do total, os quais eram ocupados por membros das duas outras ordens - o alto clero e a nobreza - que eram, ao entender de Sieyès, privilegiados sem méritos. O abade advoga pela construção de uma meritocracia baseada em uma mínima igualdade de oportunidade entre todos.

Para Sieyès os privilegiados membros da nobreza e do alto clero constituíam um corpo estranho, que nada fazia e poderiam ser suprimidos sem afetar a essência da Nação. Muito pelo contrário, pois as coisas poderiam andar melhor sem o estorvo desse conjunto parasita.

$\mathrm{Na}$ defesa do voto per capita, tema central do funcionamento dos Estados Gerais, Sieyès argumenta que a vontade nacional é o resultado das vontades individuais, assim como a Nação é o conjunto dos indivíduos. A Nação é um conjunto de indivíduos de quase 27 milhões de franceses e os privilegiados são apenas 200 mil nobres ou sacerdotes. A força da nação, do povo, está no número, já que todos os representantes, burgueses, nobres ou sacerdotes, teriam somente um voto (é o voto per capita: cada homem um voto) (SIEYÈS, 2001, p. 67).

\footnotetext{
${ }^{13}$ Sobre o tema veja-se: ARENDT, Hannah. O que é autoridade. In: Entre o passado e o futuro. 3. ed. São Paulo: Perspectiva, 1992.

14 Como diz o jusfilósofo italiano Luigi Ferrajoli os direitos fundamentais surgem historicamente como reivindicações dos mais débeis, dos mais fracos, e no caso das revoluções liberais, surgem como reivindicações da classe burguesa que iram culminar na positivação dos primeiros direitos fundamentais de liberdade (Veja-se: FERRAJOLI, Luigi. Derechos y garantías: La ley del más débil. Madrid: Trotta, 1999, 180 p.).
} 
O vigário de Chartres, também deputado eleito pelo Terceiro Estado, notadamente ocupado em estabelecer um entendimento de igualdade político-jurídica a partir da igualdade perante a lei. Característica absolutamente racionalista, de direito natural racionalista, pois não é por acaso que todas as declarações de direitos fundamentais se iniciam pela igualdade. Em sua obra famosa ele pergunta e responde: O que é o Terceiro Estado? Segue com suas perguntas: “ $O$ que é uma Nação? Um corpo de associados que vivem sob uma lei comum e representados pela mesma legislatura” (SIEYÈS, 2001, p. 69.). Dessa forma, ele ressalta a importância da lei. Sua perspectiva é puramente jurídica. Não foi objetivo da obra qualquer tipo de análise econômica ou social: o Terceiro Estado é apresentado como um bloco monolítico de quase 27 milhões de indivíduos iguais. A única distinção feita na obra é a que contrasta "privilegiados” com "não privilegiados".

Para Sieyès, a nação - no sentido de povo - se identificava com o Terceiro Estado e com a ideia de sufrágio censitário, que iria vigorar posteriormente até o final do século XIX, essa seria representada pela burguesia. Como muito bem explicou Hermann Heller, sobre a luta da burguesia para limitar o poder do Estado absoluto, no sentido que: "na Revolução Francesa, o setor burguês do povo que chegou a adquirir uma consciência política, a nação na acepção francesa, conseguiu alcançar para si a decisão consciente sobre a forma de existência do Estado e, com isso, o poder constituinte" (HELLER, 1968, p. 326).

Embora o Terceiro Estado possuísse todo o necessário para constituir uma nação, na interpretação de Sieyès no momento pré-revolucionário ele nada era na França do antigo regime, pois a nobreza havia usurpado os direitos do povo, oprimindo-o, instituindo privilégios e exercendo as funções vitais no serviço público. O que é o Terceiro Estado? Resposta de Sieyès naquele momento pré-revolucionário: Nada! Contra esta situação, o Terceiro Estado reivindicava apenas uma parte do que, por justiça, lhe caberia. A burguesia não queria ser tudo, mas queria, no mínimo, escolher seus representantes no próprio Terceiro Estado, ter igual número de deputados que a soma dos outros dois estamentos e poder ter as votações nos Estados Gerais por cabeça, não por ordem.

Sieyès (2001, p 78) escreveu que o povo "quer ter verdadeiros representantes nos Estados Gerais, ou seja, deputados oriundos de sua ordem, hábeis em interpretar sua vontade e defender seus interesses". Sobre a desigualdade do absolutismo monárquico quanto ao poder de decisão, Sieyès (2001, p. 78) anotou que ao Terceiro Estado “(...) é certo que não possa vir a votar nos Estados Gerais, se não tiver uma influência pelo menos igual à dos privilegiados, e com um 
número de representantes igual ao das outras duas ordens juntas”. E criticou a vazia decisão de somente duplicar o números de deputados do Terceiro Estado enquanto “(...) esta igualdade de representação se tornaria perfeitamente ilusória se cada câmara votasse separadamente". Assim, Sieyès conclui categoricamente que "o Terceiro Estado pede, pois, que os votos sejam emitidos por cabeça e não por ordem".

Quem interpreta adequadamente, ao que nos parece, essa não absorção de Sieyès é Aurélio Wander Bastos na introdução brasileira da obra de Sieyès (2001, p xxiii):

Sendo um ativista político e, quem sabe, por isto mesmo, Sieyès está muito mais preocupado com a pragmática eleitoral do que com as teorias sobre formas de organização de um novo Estado. Para ele o que importa é definir meios e alternativas eleitorais que transfiram o controle do poder das ordens privilegiadas - o clero e a nobreza (os notáveis) - para o Terceiro Estado, ou o estado plano como também à época se denominou.

De todas as formas, procurando fundamentar estas reivindicações no Direito, Sieyès desenvolveu o seu pensamento jurídico nos dois capítulos finais do famoso folheto, partindo do modo representativo de governo para chegar, pela primeira vez, a uma distinção entre o Poder Constituinte e os poderes constituídos (CRUZ, 2002, p. 60).

Sieyès distinguiu três épocas na formação das sociedades políticas. Na primeira, há uma quantidade de indivíduos isolados que, pelo fato de quererem reunir-se, têm todos os direitos de uma nação, restando apenas exercê-los. Na segunda época, reúnem-se para deliberar sobre as necessidades públicas e os meios de provê-las. A sociedade política atua, então, por meio de uma vontade real comum. Na terceira época, surge o governo exercido por procuração: os representados escolhem seus representantes para velar por suas necessidades. Neste momento já não atua uma vontade comum real, mas sim, uma vontade comum representativa. Os representantes não a exercem por direito próprio e nem sequer têm a plenitude do seu exercício.

Em última análise, ao procurar fundamentar juridicamente as reivindicações da classe burguesa, Sieyès foi buscar fora do ordenamento jurídico positivo, que ele considerava injusto, um Direito superior, o Direito Natural do povo de autoconstituir-se, a fim de justificar a renovação da mesma ordem jurídica, ou seja, através do Poder Constituinte (CRUZ, 2002, p. 60). A justificativa do exercício do Poder Constituinte será um fator metajurídico que irá corrigir a uma situação de injustiça extrema. 


\section{A ASSEMBLÉIA DOS ESTADOS GERAIS SE CONSTITUI EM UMA ASSEMBLÉIA NACIONAL CONSTITUINTE: A VITÓRIA DO TERCEIRO ESTADO RUMO A REVOLUÇÃO QUE COLOCARÁ FIM AO ANTIGO REGIME}

Os acontecimentos históricos que seguem a eleição e reunião dos chamados Estados Gerais darão razão a teoria e obra do abade Sieyès. Alguns detalhes são interessantes serem expostos para que tenhamos uma idéia do clima da reunião da Assembléia dos Estados Gerais.

Antes da reunião de 5 de maio de 1789 em Versalhes, segundo Mathiez (p. 55), a Corte fez questão de manter rigorosa diferença de tratamento e uma irritante separação entre os deputados do clero e da nobreza com relação aos deputados da burguesia. O rei recebia aos deputados das duas ordens privilegiadas na sala de audiências cercado das maiores atenções e pompas, enquanto que recebia aos deputados da ordem dos comuns com desdém no quarto de dormir e em grupos. Cada detalhe fazia crescer a revolta no espírito dos burgueses. "O Terceiro Estado será obrigado a usar um traje oficial todo preto, que, na sua simplicidade, contrastava de maneira chocante com as rendas e os chamalotes dourados das duas primeiras ordens" (ibidem). Historicamente marcou o desfile de abertura dos Estados Gerais, em 4 de maio de 1789, essa diferença que assinalava para uma exagerada singeleza dos trajes dos membros do Terceiro Estado, ainda que todas essas tentativas de humilhação fizessem com que o Terceiro Estado tenha se unido ainda mais. Enquanto as portas principais se abriam para a entrada dos deputados do clero e da nobreza, finalizando um desfile com toda a pompa possível, os deputados do Terceiro Estado por uma porta lateral entravam na sala reservada à primeira reunião da Assembléia dos Estados Gerais no Palácio de Versalhes. Impressiona o público assistente o contraste das roupas luxuosas das duas ordens superiores com o detalhe da vestimenta de todos os membros do Terceiro Estado: todos de negro, fato de deixava claro a união da ordem mais numerosa e considerada inferior. Na sessão de abertura no dia seguinte, 5 de maio, ainda mais agravaram a má impressão e a irritação dos membros do Terceiro Estado causada pela falta de tato do rei Luis XVI, que “(...) em tom queixoso e sentimental (...) preveniu aos deputados contra as tendências inovadoras e convidou-os a se preocuparem, antes de mais nada, com os meios de encher as arcas do tesouro" (MATHIEZ, p. 59-60). Por último, o primeiro ministro Necker fez um enfadonho e longo discurso cheio de cifras e não se pronunciou sobre a importantíssima questão do voto per capita para a decepção do todos. 
Após o pronunciamento de Necker, ficou claro que o Terceiro Estado sempre perderia por dois a um pelas regras de 1614 do voto por ordem. Ao dia seguinte os representantes dos comuns começam a campanha pelo voto por cabeça. Após semanas de conversações e discussões, os deputados da burguesia conseguem o apoio da maioria do clero - de seus representantes que pertenciam ao baixo clero - e de parte da nobreza liberal para o voto por cabeça. Diante desse fato, declaram-se representar a 98\% dos franceses, e por isso no dia 17 de junho se proclamam, levando em conta as idéias de Sieyès, uma Assembléia Nacional. O rei tenta dissolvê-los, fechando a sala do Palácio de Versalhes na qual se reuniam. Os deputados não se intimidam, buscam outra sala pelo palácio adentro e numa sala usada pela corte para praticar um jogo da época, a sala do Jogo da Péla, certos de sua missão histórica juram: “(...) nunca separar-se e reunir-se em todos os lugares onde as circunstâncias o exigirem até que a Constituição seja estabelecida e assentada sobre fundamentos sólidos" (EPIN, 1989, p. 26). É o famoso juramento da Sala do Jogo da Péla do dia 23 de junho de 1789, com o qual a Assembléia Nacional se proclama agora como uma Assembléia Nacional Constituinte, a primeira do constitucionalismo moderno.

A partir desse fato, Luis XVI continua a dar mostras de sua total falta de tato, no mesmo 23 de junho reage e ameaça aos deputados discursando no sentido de que ele era o rei e único e verdadeiro representante dos franceses afirmando que nenhum projeto aprovado pela assembléia rebelde teria força de lei sem sua aprovação. A miopia de Luis XVI não lhe fazia ver que a Revolução apenas começava. Como prova de força o rei concentra suas tropas em Versalhes e Paris, preparando a dissolução da autoproclamada Assembléia Nacional Constituinte. Demite Necker, ainda popular por suas posições comedidas. O conde de Mirabeau que lhe terá que dizer publicamente como resposta ao seu intempestivo pronunciamento: "é uma revolta? Não, majestade, é uma revolução" (MADELIN, 2004, p. 52).

Os poucos quilômetros de distância entre Versalhes e Paris, uns 20 km, permitiam que as notícias chegassem rapidamente à capital. Os parisienses saíam às ruas, reuniam-se em locais públicos para informar, discutir e decidir que havia chegado o momento de uma rebelião popular sem precedentes, certamente não se sabia que se tratava de uma Revolução que iria marcar toda a humanidade. Evidentemente que o espírito de revolta tomou conta do movimento que saiu de todo e qualquer possível controle, levando a um sem fim de acontecimentos entre os quais o de 14 de julho é o mais emblemático, a tomada da Bastilha, e que marca a data da Revolução Francesa. A notícia irá influencia a todo o mundo da época, nas palavras de Michelet (1989, p. 156), sobre o episódio da ocupação da Bastilha por populares teve um significado simbólico 
ainda maior: "Todas as nações, à notícia de sua ruína, acreditaram-se libertadas". A queda da Bastilha foi a primeira verdadeira vitória popular, uma demonstração de força sem precedentes, pois era a famosa prisão política da monarquia absoluta. É certo dizer que o sentimento de medo acompanhou aos franceses no período revolucionário. Os boatos nas cidades eram muitos e no campo a partir de julho instalou-se o que Lefevbre (1989, p. 173) chamará de o grande medo de 1789, a revolta camponesa provocada pelas más colheitas dos últimos anos, pelo desemprego e a fome, pelos séculos de exploração e pelas dívidas que os faziam servos eternos dos senhores donos das terras. Castelos foram incendiados, nobres tiveram que fugir para não morrer assassinados pela ira que se instalou pelos condenados a viver como miseráveis.

Foi então que a Assembléia Nacional Constituinte, agora instalada em Paris, resolve no dia 4 de agosto decretar o fim do feudalismo, o fim dos direitos feudais, declarando a igualdade entre todos com o fim dos privilégios. Ato seguinte a Assembléia decide aprovar uma Declaração de Direitos do Homem, para deixar claro que os Direitos Naturais do Homem deveriam ser estipulados antes mesmo de terminar sua função de dotar a nação francesa de uma constituição. Então em 26 de agosto de 1789 é aprovada a Declaração de Direitos do Homem e do Cidadão composta por 17 artigos. Na Declaração aprovada estão estipulados os direitos do homem e do cidadão burguês revolucionário de 1789 .

Por culpa de muitos acontecimentos posteriores demorará a finalização dos trabalhos da constituinte instalada em 1789; entre outros, a família real é trazida a força pelo povo ao Palácio das Tulherias (Palais des Tuileries), os nobre exilados começam a organizar com algumas monarquias vizinhas uma guerra contra-revolucionária, o rei e rainha tentam fugir da França em julho de 1790, a discussão e aprovação da constituição civil do clero, a guerra contrarevolucionário, e assim somente em 1791 é finalizado o exercício do poder constituinte e dissolvida a Assembléia Nacional Constituinte. Convocada agora eleições para uma Assembléia Legislativa. Todo esforço resultaria tarde demais, pois a Revolução seguia e a Constituição Monárquica aprovada já não cabia para a França de então, uma vez que a constituição de 1791 ficaria pouquíssimo tempo em vigor, pois a guerra contra-revolucionária e sobretudo as jornadas do dia 10 de agosto, levariam a convocação de uma nova Assembléia Nacional Constituinte: agora chamada de Convenção Nacional, em homenagem à Convenção da Filadélfia de 1787, para novamente exercer o poder constituinte. Pois uma nova revolução dentro da Revolução havia acontecido, um novo fator metajurídico havia acontecido, o rei e a família real haviam sido presos nas jornadas do dia 10 de agosto e a República havia sido proclamada e em 22 de 
setembro uma nova era, com calendário novo, se inaugurava e uma nova constituição seria elaborada.

Para o nosso trabalho é importante ressaltar que a obra do abade Sieyès vigorou e sobreviveu ao seu tempo. Também eleito deputado na nova assembléia constituinte, o vigário de Chartres seguiria sua função de mediador entre a direita dos chamados girondinos e a esquerda mais feroz dos montanheses jacobinos. Certamente a história da Revolução Francesa é apaixonante, mas o objeto do presente texto é confirmar a afirmação que a Teoria do Poder Constituinte teve sua origem na obra do abade e que é atual até hoje.

\section{CONSIDERAÇÕES FINAIS}

A título de considerações finais podemos dizer que:

O pensamento de Sieyès desenvolveu-se nos moldes do direito natural racionalismo iluminista, do contratualismo e da ideologia liberal da época. Ele dedicou-se a construir um conceito racional de Poder Constituinte, levando em conta o problema da sua natureza e da sua titularidade, bem como apresentando a sua solução. Sobre a natureza jurídica do Poder Constituinte admitindo-se a positividade como o único modo de ser do Direito e sendo certo que o Poder Constituinte é anterior ao Direito Positivo, não pode ser considerado um poder jurídico (CRUZ, 2002, p. 60-61).

Depreende-se daí que o Poder Constituinte Originário, a princípio, não está, necessariamente, obrigado pela ordem pretérita e, portanto, não se funda em nenhum poder jurídico (CRUZ, 2002, p. 61). Funda-se sim em um poder político e metajurídico que pode ser através do nascimento de um novo país (independência, separação, fusão etc), de uma Revolução (legítima), de um golpe de Estado (ilegítimo exercício do Poder Constituinte) e de um autêntico processo de redemocratização.

O Poder Constituinte é, assim, um poder advindo da soberania natural do conjunto da sociedade, e é seu titular legitimo o povo que o exerce através de seus representantes. 


\section{REFERÊNCIAS}

ARENDT, Hannah. O que é autoridade. In: Entre o passado e o futuro. Tradução de Mauro W. Barbosa de Almeida. 3. ed. São Paulo: Perspectiva, 1992.

CRUZ, Paulo Márcio. Fundamentos do direito constitucional. 2.ed. Curitiba: Juruá, 2002.

DALLARI, Dalmo de Abreu. Elementos de Teoria Geral do Estado. 27 ed. São Paulo: Saraiva, 2007.

DIPPEL, Horst. História do Constitucionalismo Moderno: novas perspectiva. Lisboa: Fundação Calouste Gulbekian, 2007. Título original:

EPIN, Bernard. Revolução Francesa. São Paulo: Brasiliense, 1989.

FERRAJOLI, Luigi. Derechos y garantías: La ley del más débil. Tradução de Perfecto A. Ibañez e Andrea Greppi Madrid: Trotta, 1999. Título original:

FIORAVANTI, Maurizio. Constitución: De la antigüedad a nuestros días. Tradução: Manuel Martínez Neira. Madrid: Trotta, 2001. Título original: Costituzione.

FIORAVANTI, Maurizio. Constitucionalismo: Esperiencias históricas y tendencias actuales. Tradução: Adela Mora Cañada e Manuel Martínez Neira. Madrid: Trotta, 2014. Título original: Costituzionalismo.

GONZÁLEZ VICÉN, Felipe. Teoría de la Revolución: Sistema e historia. 2 ed. Madrid: Plaza y Valdés, 2010.

HAMPSON, Norman. Historia social de La Revolución Francesa. Tradução de Javier Pradera. Madrid: Alianza Universidad, 1970. Título original: A Social History of the French Revolution.

HELLER, Hermann. Teoria do Estado. Tradução de Lycurgo G. da Motta. São Paulo: Mestre Jou, 1968. Título original:

LEFEBVRE, George. O surgimento da Revolução Francesa. Tradução de Cláudia Schilling. Rio de Janeiro: Paz e Terra, 1989. Título original: Quatre-vingt-neuf.

MADELIN, Louis. Sieyès. In: Los hombres de la Revolución Francesa. Buenos Aires: Vergara, 2004. p. 301-333. Titulo original: Les hommes de la Révolution, 1928.

MADISON, James; HAMILTON, Alexandre; JAY, John. Os artigos federalistas. Tradução de Maria Luiza Borges. Rio de Janeiro: Nova fronteira, 1993.

MATHIEZ, Albert. História da Revolução Francesa, Vol I: A queda da realeza (1787-1792). Tradução de Paulo Zincg. São Paulo: Atena Editora, s.d. Título original: 
MICHELET, Jules. História da Revolução Francesa: da queda da Bastilha à festa da federação. São Paulo: Cia. Das Letras, 1989.

PECES-BARBA, Gregorio. Curso de Derechos Fundamentales: teoria general. Madrid: Universidad Carlos III de Madrid, 1995.

PÉRONNET, Michel. Revolução Francesa em 50 palavras-chaves. Tradução de Rita Braga. São Paulo: Brasiliense, 1989. Título original: Les mots clefs de la Révolution Française.

RUIZ MIGUEL, Alfonso. Una filosofía del Derecho en modelos históricos: De la antigüedad a los inicios del constitucionalismo. Madrid: Trotta, 2002.

SIEYÈS, Emmanuel Joseph. A constituinte burguesa. 3.ed. Rio de Janeiro: Lumen Juris, 2001. Titulo original:Qu'est-ce que le Tiers État. 